Anker Brink Lund:

\title{
Statens informationsvirksomhed og dens politiske funktioner
}

Anskuet isoleret fxemtræder myndighedernes informationsindsats uproblematisk som et gode $i$ sig selv. Alt andet lige er det tilsyneladende bedre at blive informeret om love $\mathrm{m} \cdot \mathrm{v}$. end ikke at blive det.

Imidlertid risikerer man ved således at gøre informationsudbuddet til udgangspunkt for sin analyse, at samfundet reduceres fra at være en modsætningsfyldt produktionsstruktur til at blive opfattet som et ukompliceret interaktionssystem, l) hvor konflikter og modsætninger kan løses alene gennem informationsvirksomheden.

Ofte er informationsproblemer imidlertid blot symptomer på problemer på andre samfundsniveauer. ${ }^{2)}$ I et fors $\phi g$ på at bevæge mig ud over den informationstekniske approach og dens abstraktioner vil jeg derfor $i$ min analyse af statens informationsvirksomhed $i$ Danmark tage udgangspunkt $i$ offentlighedsteoriens totalitetsopfattelse, således som den er skitseret $i$ artiklen pp. 8-25. En sådan tilgang til stoffet kræver en kortlægning af ændringer i statsmagtens informationsindsats over tid. En samlet historisk oversigt er imidlertid endnu ikke oparbejdet, hvorfor jeg først skitsemæssigt må redegøre for den udvikling, der leder frem til statens nuværende informationstiltag. ${ }^{3)}$

1) En kritik af denne kommunikationsmodel findes bl.a. hos Anker Brink Lund, Magten over Danmarks Radio. En analyse specielt med henblik på forholdene omkring lydradioens ny hedsformidiing 19701976, Arhus 1976, pp. 3-12.

2) Jan Ekecrantz, Makten och informationen, Lund 1975, har foretaget en dybtgående unders $\not g e l s e$ af disse problemer pa grundlag af svenske erfaringer. I Danmark kan anfфres Sфren Klebak \& Chr. Horst, Fremmedarbejderes viden om social- og sundhedsvasenet, Kbh. 1977, og erfaringerne fra EFG-uddannelsen, hvor man først sparede et bel $\phi b$ pa aflønning af eleverne, for dernast - da antallet af ansфgere faldt drastigt - at bevilge et relativt stort beløb til en informationskampagne om uddannelsen.

3) Skitsen har leksikal karakter, men kan forhåbentlig lette materialeindsamlingen for kommende fors $\phi g$ pa at trænge mere i dybden med detaljer $i$ udviklingen. Således har der ikke inden for denne artikels ramme været mulighed for at problematisere of- 
Staten opfattes, jvf. figuren p. 9, som en sfære $i$ den offentlige sektor, der kan karakteriseres som en sekundær magt $i$ forhold til den primære magtbasis $i$ den private socialsfare. Den politiske offentlighed ses som den sfære, der ifølge den borgerlige selvforståelse forbinder de to samfundsniveauer.

Det er således ikke primært de enkelte organer i statsapparatet, der er artiklens genstandsomrade, men derimod den statslige informations almene funktioner inden for den nuværende danske samfundsformation. Derfor søger jeg alene at trække nogle hovedtendenser frem, hvorimod jeg ikke pratenderer at få alle detaljer $i$ de enkelte styrelser og institutioner med. Desuden har hensynet til artiklens omfang betydet, at jeg har måttet udvælge et enkelt delområde, i.e. centraladministrationens informationsvirksomhed, som fixpunkt i fremstillingen. ${ }^{4)}$

\section{En historisk skitse af udviklingen i statsinformationen}

Efter etableringen af den enevældige stat $i 1660$ skabtes den første dansksprogede avis Den danske Mercurius ved $\mathrm{kgl}$. privilegium $i$ 1666. De første aviser var som regel bivirksomheder $i$ bogtrykkerier og indskrænkede sig stort set til at bringe udenlandske efterretninger og beretninger fra hoffet, d.v.s. til at beskrive den repræsentative statsoffentlighed. 5)

Den enevaldige stat kunne derfor defensivt sikre sig kontrollen med meningsdannelsen gennem censur og andre forebyggende

(note 3 forts.)

fentlighedsteorierne, ligesom den фkonomiske og politiske baggrund må forudsættes bekendt. Så vidt muligt bygger redegørelsen for de centrale informations-beslutninger på primærkilder, men m.h.t. det almene historiske forløb har jeg været henvist til sekundære kilder om pressehistorie, især Niels Thomsen, Dagbladskonkurrencen 1870-1970, Kbh. 1970, og Svend Thorsen, Den danske presse, Kbh. 1951, og om den administrative udvikling, jvf. Ministerialforeningen (udg.), Centraladministrationen 1848-1948, Kbh. 1948, og Poul Meyer, Offentlig forvaltning, Arhus 1975 .

4) Om amters og kommuners informationsvirksomhed se de to følgende artikler $i$ dette nummer af Politica.

5) Jvf. Thorsen, op.cit. I, p. 8. Om begrebet repræsentativ statsoffentlighed se Jürgen Habermas, Borgerlig offentlighet, Kbh. 1971, pp. 4-13. 
foranstaltninger. ${ }^{6)}$ statens aktive informationsformidling indskrænkedes til udgivelsen af det lille ugeblad Kollegialtidende samt plakater og avertissementer $i$ de privilegerede blade Berlingske Tidende $i$ København og Stiftstidenderne $i$ provinsen. ${ }^{7)}$

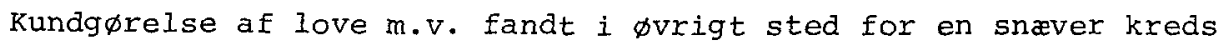
ved tinglasning, og meddelelse af retsforskrifter havde kun begrænset juridisk betydning, idet hovedparten af de statsige forordninger var gyldige; uanset om de var kundgjort eller ej. ${ }^{8}$ )

I 1830'erne supplerede statsmagten imidlertid sin politik på informationsområdet med mere offensive tiltag. Efter europæisk monster etableredes en egentlig statsavis til "Berigtigelse af de vrange Domme over de offentlige Foranstaltninger", 9 ) idet embedsbladet i 1839 omdøbtes Ny Kollegialtidende, formatet forst $\phi r r e d e s$, oplaget blev oget, og udgivelseshyppigheden fordobledes. Samtidig inddrog kongemagten en rakke private blade, f.eks. Dagen, Aftenbladet og de privilegerede aviser, som propagandainstrumenter bl.a. gennem subvention af redaktфrerne, der "ikke på samme måde som et propagandistisk og polemisk officielt organ kompromittere(de) den upartiskhed, som Christian VIII - hvor mærkeligt det lyder ikke blot havde sat sig som mål, men som han selv under de herskende forhold troede at repræsentere". 10)

6) Jvf. Danske Lov 2-21-1: "Ingen, hvo det og være kand, maa noget lade trykke, $f \phi r$ end det tilforn $i$ Kongens Universitet ere igiennemgaaet og paakient af Decano $i$ den Fakultet, som Materien hører til..." Kun $i$ en kort periode under Struenses regering mildnedes censuren, jvf. kgl, rescript af 14.9 .1770 , men ved rescript af 27.9 .1799 og plakater af 1805,1810 og 1814 blev trykkefriheden igen voldsomt indskrænket.

7) Foruden disse kundgørelses- og avertissements-privilegier, der var galdende i perioden 1792-1904, bestod privilegiesystemet af et godkendelsessystem for selve udgivelsen af periodiske skrifter (1634-1862), regler for postbes $\phi$ rgelse af aviser (1724-1848) og afgift-og censurbestemmelser for formidling af politiske nyheder (1810-1851).

8) Jvf. $\mathrm{kgl}$. rescript af 27.5.1813. Om tinglæsning se $i \phi v r i g t$ V. Bentzon, Retskilderne (hafte 1-3), Kbh. 1901-07, pp. 28 ff. og A.W. Scheel, Privatrettens almindelige Deel, I, Kbh. 1865, pp. $119 \mathrm{ff}$.

9) Introduktionsnummeret af Ny Kollegialtidende (her citeret efter Poul Jensen, Presse, penge og politik 1839-48, Kbh. 1971, p. 283).

10) Ibid., p. 284 . 
"De herskende forhold", som betingede denne oplysningsstrategi $i$ informationspolitikken, kan karakteriseres som en legitimationskrise for enevælden. Især fra hertugdømerne artikuleredes krav om ændringer $i$ styreformen. Censur og privilegiesystem var ikke længere tilstrækkeligt til at dæme op for disse krav, bl.a. fordi dele af pressen havde ændret karakter $i$ retning af en egentlig meningspresse. Udbygningen af transportsystemet og uddannelsen bet $\phi d$ samtidig, at der nu var tale om egentlig massekommunikation. Desuden etableredes en række kritiske blade, der på liberalistisk grundlag kritiserede den representative statsoffentlighed $i$ fuld åbenhed. Indgreb, beslagleggelser og straf førte kun til større offentlighed omkring oppositionen, og nationalliberalismen fandt støtte hos mange yngre embedsmænd i København.

Denne udvikling $i$ retning af en kritisk, debatterende borgerlig offentlighed som formidier af de okonomiske og politiske modsatninger $i$ samfundet var medvirkende til, at den enevældige stat blev tvunget til mere aktivt at forholde sig til publikum, hvilket kulminerede ved indkaldelsen af den grundlovgivende rigsforsamling i 1848 .

$\underline{1848-1870}$

Juni-grundloven og udvidelsen af trykkefriheden kan ses som et fors $\varnothing \mathrm{g}$ på at gennemf $\varnothing$ re et liberalt offentlighedsprincip $i$ staten. 11) Hovedlinierne $i$ denne informationspolitik var at abne for offentlighedens adgang til at kontrollere statsmagten, men uden at statsapparatet selv aktivt skulle styre informationen. Formidlingsopgaven burde $i$ stedet overlades til den private dagspresse.

De nationalliberale krævede fuld offentlighed i statsstyrelsen. Deres strategi slog imidlertid kun igennem i Rigsdagen ved indførelsen af mødeoffentlighed og udgivelse af Rigsdagstidende. Derimod blev løfteparagraffen om offentlighed $i$ domstolene forst indfriet $i$ 1919, og med undtagelse af en begrænset efter-

11) Ved $\mathrm{Kgl}$. rescript af 24.1.1848 standsedes alle verserende straffesager imod pressen, og ved en provisorisk forordning af 24.3 .1848 og siden ved grl. \$91 (nu \$77), presseloven af 3.1 . 1851 og postloven af 11.3 .1851 skabtes formel ytringsfrihed, ligesom dele af det gamle privilegiesystem afskaffedes. Desuden pålagdes staten kundgørelsespligt for vedtagne love ( $g r l$. §22). 
følgende aktindsigt for ans $\phi g e r e$ og klagere hjemlet ved lov af 2 . februar 1866 blev offentlighedsprincippet heller ikke sat igennem i centraladministrationen.

De embedsmandsdominerede regeringer afviste offentlighed $i$ forvaltningen med henvisning til magtdelingsprincippet og ministeransvarligheden. På grund af forvaltningens ringe omfang og den begrænsede brug af delegation mente man desuden, at spørgsmålet var relativt ubetydeligt i praksis.

Kollegialtidende fortsatte under navnet Departmentstidende og omtalte kun regeringens forslag og forordninger. De privilegerede aviser bevarede eneretten på statslige bekendtg $\varnothing r e l-$ ser, og som følge af krigsforholdene skete der snart igen indskrankninger $i$ pressefriheden.

$\emptyset$ nsket om ustyret information om statsadministrationen blev dog flere gange rejse af de nationalliberale med henvisning til forfatningens lighedsgrundsætning. Det skete især $i$ form af krav om fuldstændig afskaffelse af presseprivilegierne og etableringen af en rigsdagskontrolleret lovtidende til erstatning for den embedsmandsdominerede Departementstidende og de administrative lovsamlinger.

I 1853 foranstaltede regeringen en unders $\phi g e l s e$ af mulighederne for en mere tidsvarende bekendtg $\not r e l s e s m a d e$ for love og forordninger. Som følge af problemer med indpasning i helstatsforfatningen stilledes unders $\phi g e l s e n$ imidlertid $i$ bero, og da undersфgelserne genoptoges i 1863-64, politiseredes spфrgsmålet, idet det juridiske aspekt blev kædet sammen med et politisk krav om ophævelse af de resterende presse-privilegier.

Ved tronskiftet i 1863 fornyedes privilegierne til Berlingske Tidende og stiftstidenderne kun "indtil videre", og den daværende nationalliberalt dominerede regering havde $i$ nogen tid arbejdet med planer om at erstatte de private blades kundgørelsesmonopol med en uvildig statstidende, idet de ikke fandt, at staten burde sikre "Opretholdelse af Blade, der efter hele deres Holdning ikke er egnede til støtte af Regeringen". ${ }^{12}$ ) De privile-

12) Indenrigsministerens skrivelse af 20.5 .1860 (her citeret efter Folketingets Forhandlinger 1901/02, sp. 5021). 
gerede aviser var saledes blandt de, der mest indædt havde bekæmpet afskaffelsen af enevælden og den gamle sociale orden.

Bestræbelserne førte ikke til noget resultat på grund af nederlaget $i$ krigen og den deraf følgende svækkelse af de nationalliberale. Da sagen blev bragt op igen $i$ efteråret 1866, strandede den på modstand fra indenrigsminister J.B.S. Estrup, der $\varnothing n-$ skede stiftstidendernes privilegier opretholdt.

I et forslag til oprettelse af en lovtidende, som blev forelagt landstinget af ministeriet Frijs' 20.12.1869, var hele spфrgsmalet om presse-privilegierne taget ud af sagen. Under debatten blev spørgsmålet dog inddraget af Plough og Lehmann, der krævede, at man samlede alle $\varnothing v r i g h e d e n s$ bekendtg $\varnothing r e l s e r ~ i$ en Statstidende, hvorved konkurrenceforvridning $i$ pressen og den administrative styring af informationen kunne undgås. ${ }^{13}$ )

Resultatet af den efterfølgende folketingsbehandling blev et kompromis, hvorefter det vedtoges at oprette en Lovtidende og en Ministerialtidende, der skulle afløse Departementstidende, hvorimod de resterende presseprivilegier blev opretholdt uændret. ${ }^{14}$ )

$1870-1901$

Under forfatningskampen politiseredes spørgsmålet om statens informationsvirksomhed i stigende grad. Tidligere havde gărdmændene $i$ oppositionen st $\phi$ ttet godsejer-regeringens strategi, hvorved befolkningen skulle have så mange informationer som muligt, hvorimod man anså det for mindre væsentligt, om informationen var styret af regeringen eller blev formidlet gennem pressen. Det fremgår bl.a. af, at to Venstre-folketingsmand $i$ efteråret 1871 fremsatte private forslag til stфrre regeringskontrol med $\phi v r i g h e d e n s$ bekendtgørelser. I første omgang var motiverne bag. forslagene blot at sikre besparelser for staten og flytte bekendtgørelses-monopolet fra de lidet udbredte stiftstidender til de blade, der havde større udbredelse $i$ de lokale områder. Forslagene nåde imidlertid ikke at blive fardigbehandlet i rigsdagssamlingen 1871/72, og da regeringen $i 1872$ fremsatte et forslag på disse præmisser, afviste Venstre-repræsentanterne den

13) Landstingets Forhandlinger 1869/70, sp. 1391-1427.

14) Lov af 25.6.1870, jvf. anordning af 24.9.1870. 
idé, de selv havde fremsat året forud, "da der er passeret Noget siden den Tid". 15)

Med de voksende modsætninger mellem Højre (regeringen) og Venstre (folketingsflertallet) og oprettelsen af egentlige partipolitiske aviser, фnskede Venstreoppositionen nu en så ustyret informationsformidiing som muligt, bl.a. med følgende begrundelse: ${ }^{16)}$
"Følgen af denne Lov vil blive, at Regeringen ikke alene, som nu, har et stort Blad i København til Raadighed som officielt Blad, hvilket, naar Regeringen er en Paxtirege- ring $i$ meget høj Grad saaledes som den nuværende, bliver Partiblad, men der skabes tillige en Række af lokale Partiblade, som skaffes en kunstig Udbredelse. Det bli- ver officielle Organer for Regeringen og lokale Embeds- mænd, og dette sidste kan i mange Tilfælde være endnu fordærveligere end det første."

I stedet stillede Venstre en rakke ændringsforslag, der indebar ophævelse af privilegierne og skabelse af en statstidende for hele landet. En sådan $1 \varnothing$ sning var imidlertid uacceptabel for Højre, som derfor syltede forslaget $i$ et Landstingsudvalg.

Partipolitikken havde således vundet indpas $i$ den tilsyneladende magtneutrale borgerlige offentlighed - også på informationspolitikkens område. Højre benyttede $i$ voksende omfang sin regeringsmagt til skjult partipropaganda $i$ pressen, 17 hvilket bl.a. blev muliggjort af den klausul, som ministeriet Estrup fra 1883 lod indføje $i$ privilegiebetingelserne: $\left.{ }^{18}\right)$

"Tidendes Redaktion blev at forestaa af en paalidelig Mand, som af vor Indenrigsminister dertil anses for skikket... Bevilingshaveren skal derhos i alle Tilfælde, hvor der maatte opstaa Spфrgsmaal om vor Bevillingsrets Mening, være vor Indenrigsminister afgørende undergiven."

Desuden anvendte regeringen sin magt til i praksis at genindføre censuren, ligesom man gennem den provisoriske presselov af 13.8 . 1886 reelt satte pressefriheden ud af kraft.

15) Folketingets Forhandlinger $1872 / 73$, sp. 1557.

16) Ibid., sp. $1552 \mathrm{f}$.

17) Om regeringens kontrol med telegrambureauet Ritzau og eksempler på H $\phi j$ repolitikeres og embedsmænds anonyme artikler $i$ de privilegerede blade se Thorsen, op.cit. I, p. 165.

18) Skrivelse fra Indenrigsministeren til Aarhuus Stiftstidende (her citeret efter Folketingets Forhandlinger 1901/02, sp. $5023 f$.). 
Venstre og det fremvoksende Socialdemokrati anlagde på den baggrund som opposition en defensiv strategi. De krævede respekt for den grundlovsikrede ytringsfrihed, mere offentlighed omkring forvaltningen, eller $i$ det mindste at regeringens implicitte $\mathrm{H} \varnothing j$ re-propaganda blev gjort mere explicit og dermed mere kontrollabel, f.eks. igennem oprettelsen af en officiel statstidende.

$\underline{1901-1914}$

Efter systemskiftet var der $i$ alle partier er udbredt ønske om at begrænse regeringens muligheder for at styre informationsformidlingen og tilstræbe et ustyret offentlighedsprincip i informationspolitikken.

Højre kunne med anerkendelsen af folketingsparlamentarismen ikke regne med regeringsmagten $i$ en overskuelig fremtid og фnskede derfor at svække kommende regeringers manipulationsmuligheder og eventuelt sikre sig de privilegerede blades partiloyalitet.

Socialdemokratiet var i fard med at opbygge sin egen partipresse og фnskede ingen konkurrenceforvridning, ligesom man $i$ partiet havde sin egen partiskoling. En styret regerings-information var derfor overflødig.

Venstre havde ganske vist regeringsmagten og benyttede da også i første ongang sin position ved at tildele Aalborg Amtstidende privilegiet for Aalborg Stift $i$ 1901. I ministeriet Deutzner havde man desuden planer om at knytte Østsjællands Folkeblad til sig som officielt regeringsorgan $i$ stedet for Berlingske Tidende. ${ }^{19)}$ Men ud fra sit liberalistiske grundsyn og belært af forfatningskampens erfaringer valgte Venstre dog at foreslå privilegierne endeligt afskkaffet og $1 \phi$ se problemet med $\phi v r i g h e d e n s$ kundgørelser ved etableringen af en embedsmandsredigeret statstidende, jvf. Iov af 23. januar 1903, hvori det $i$ \$1 hedder:

"Der udgives ved offentlig Foranstaltning en statstidende, som udkommer hver $S \phi g$ nedag. I denne indrykkes de statslige og andre offentlige Kundgфrelser, der if $\phi$ lge Lovgivningen for Tiden skulle optages $i$ "Berlingske Tidende" og de ved $\mathrm{Kgl}$. Bevilling dertil autoriserede Blade uden for kjøben-

19) Thorsen, op.cit. I, p. 236 : 
havn. I statstidende kan endvidere indrykkes, hvad Regeringen finder Anledning til at meddele Offentligheden."

Især denne sidste (af mig fremhavede) passus gav anleaning til principiel debat. Oppositionen frygtede, at regeringen kunne misbruge bestemmelsen til politisk propaganda, og under debatten blev det derfor fastslåt, at statstidende alene kunne bringe rent administrative oplysninger. 20 )

Statstidende-loven, "Hvorved Pressens Udskillelse som et selvstændigt organ for Meningsdannelse og Samfundskontrol jo var blevet endelig fuldbyxdet", 21 ) sikrede en mere fri konkurrence på dagbladsområdet, hvor man omkring l. Verdenskrig fik udviklet et pluralistisk fire-blads-system $i$ store dele af landet. 22

Også gennem andre reformer $\varnothing$ gedes mulighederne for folkelig kontrol med statsmagten. Der etableredes forskellige parlamentariske nævn og råd, som skulle sikre Folketingets kommunikation med den til enhver tid siddende regering, og nye fagministerier sikrede private erhvervsinteresser bedre kontakt med statsadministrationen. Hertil kom, at der gennem skolereformlovene blev skabt en bedre uddannelse for større dele af befolkningen og dermed grundlag for bredere participation i det politiske liv.

Derved søgte man ideen fra midten af 1800-tallet om en debatterende og kontrollerende borgerlig offentlighed mellem den private sektor og staten etableret $i$ praksis. Men $i$ mellemtiden havde samfundsstrukturen ændret karakter. Med bøndernes og arbejderklassens indtrængen $i$ den borgerlige offentlighed gjorde interesseorganisationerne og partierne efterhanden idealet om et publikum af lige og frie individer illusorisk: offentligheden blev ikke den sfære, hvor samfundets almenvilje udmøntedes i magtneutral og rationel almeninteresse. Derimod blev den politiske offentlighed stedet, hvor magtfulde særinteresser kæmpede imod hinanden.

20) Landstingets Forhandlinger 1902/03, sp. 430.

21) Thorsen, op.cit. II, p. 109.

22) Om udviklingen af fireblads-systemet, der kulminerer i $1910^{\prime}$ - erne, se Niels Thomsen, op.cit., pp. 217-238. 
$\underline{1914-1930}$

Den liberalistiske offentligheds "forfald"23) blev tydeliggjort under 1 . Verdenskrig. Interesseorganisationerne var nu direkte inddraget i statsstyrelsen, og den spændte internationale situation og de hjemlige rationeringer fik statsmagten til at føre en mere offensiv informationspolitik. Offentlighedsprincippet udskiftedes atter med et oplysningsprincip.

Gennem prssemøder og lukkede sammenkomster med dagbladenes redaktører styrede regeringen nyhedsformidlingen, og gennem $\phi$ get annoncering $i$ dagspressen voksede strømen af statslig information til befolkningen. Tydeligst slog oplysningsstrategien igennem $i$ Udenrigsministeriet, hvor man etablerede et egentligt pressebureau, 24) der under opsyn fra repræsentanter for de fire store politiske partiers presse censurerede telegrammer til og fra Danmark.

Venstre og Det konservative Folkeparti kritiserede den Radikale regering og dens socialdemokratiske støtteparti for at udnytte situationen til parti-propaganda. Efter krigen søgte VK uden større held at begrænse statens indflydelse på opinionsdannelsen, bl.a. gennem krav om besparelser $i$ statens papir- og annonceudgifter og forslag om nedskæringer $i$ omfanget af de statslige tidender. ${ }^{25)}$

Når disse bestræbelserpå at begrænse statens intervention $i$ informationsformidlingen led skibbrud, skyldtes det bl.a., at et nyt element trængte ind i debatten om statens informationspolitik: spфrgsmålet om фkonomisk støtte til dagspressen.

Pressen havde $i$ begyndelsen af århundredet investeret store summer $i$ ny teknik og lanceret nye typer af aviser, der, var partipolitisk ubundne og baseret på sensations-journalistik og løssalg. Derved blev bladhusene mere sårbare over for svingninger $i$ de $\phi$ konomiske konjunkturer, og efter krigsperiodens vækst $i$ oplag og annoncer oplevede dagbladene en nedgangsperiode. Trods ideologiske betænkeligheder $\varnothing$ nskede mange udgivere derfor at fastholde

23) Jürgen Habermas, op.cit., pp. 131-168.

24) Om udviklingen $i$ Udenrigsministeriets informationsvirksomhed se Betankning 636-1972.

25) Jvf. 2. Betænkning afgivet af Administrationskommissionen af 30.6.1923, Kapitel VII. 
den udvidede statslige annoncering, og det. blev hilst velkommen, 26) da staten med postloven af 28. september $1918 \mathrm{gav}$ en indirekte pressestøtte gennem nedsatte posttakster - en praksis som er opretholdt $i$ alle senere postlove.

En mere direkte statsintervention på kommunikationsområdet skete ved etableringen af Statsradiofonien i 1925. Da der ikke var tilstrakkelige kanaler til, at de store partier hver kunne fa sin radiosender, og ikke risikovillig kapital nok til, at private virksomheder ville påtage sig opgaven, overlod Folketinget radiofonien til staten. Dog således at Folketinget gennem Radioradet bevarede indsigt $i$ driften. Den private presse sikredes samtidig kontrollen med radioens nyhedsformidling og fik derved sikkerhed for, at radiomediet ikke uhindret kunne anvendes til regeringspropaganda eller påføre pressen konkurrence på nyheds- og reklameomrădet. 27)

$1930-1945$

I Rigsdagen udkrystalliserede der sig efterhånden to modstridende synspunkter på informationspolitikken. Venstre og Det konservative Folkeparti tilstræbte et offentlighedsprincip, hvorefter meningsdannelsen i størst muligt omfang skulle overlades til borgerne, hvilket $i$ praksis ville sige de politiske partier, dagspressen og - $i$ begrænset omfang - interesseorganisationerne. ${ }^{28}$ )

Socialdemokratiet satsede derimod nu bredt på hele befolkningen og $\phi n s k e d e$ at anvende statsapparatets muligheder for at oplyse borgerne om deres rettigheder og pligter. ${ }^{29)}$ Det radikale Venstre støttede stort set dette oplysningsprincip.

Denne offensive informationspolitik sфgte regeringen Stauning-Munch at gennemføre $i$ 1930'erne, bl.a. under henvisning til behovet for en mere effektiv samfundsstyring som folge af den internationale krise og den sociale uro $i$ befolkningen. Det af-

26) H.R. Brфcker, Dagspressen, Skive 1945, pp. 257-274.

27) Om beslutningsprocessen bag etableringen af statsradiofonien se Roar Skovmand, DR 50 (1975), pp. 11-50.

28) Jvf. bl.a. udtalelsen fra Venstres Landsmode aftrykt i Folketingsårbogen $1937 / 38$, p. 376 .

29) Jvf. Socialdemokratiets arbejdsprogram Danmark for Folket, 1934 . 
spejledes $i$ en række lovgivningsinitiativer, der dog for størstepartens vedkommende modificeredes af VK-flertallet $i$ Landstinget. Regeringen foreslog således statstidendes dækningsområde udvidet. Argumenterne herfor var dels besparelsesmuligheder, dels skabelsen af en oplysningspligt for visse "semi-statslige" foretagender (sparekasser, fondsbørsvekselerer og forsikringsselskaber), dels at skabe større folkelig interesse for statens dagblad. Regeringen fremsatte sit forslag herom fire gange i perioden 193337. men først efter at vasentlige dele af averteringspligten var udtaget af forslaget, kunne det gennemføres som lov af 31 . marts 1937 .

Parallelt hermed prøvede regeringen at gennemf $\phi r e$ to andre love af informationspolitisk betydning, i.e. en folkeskolereform, der især skulle højne vidensniveauet hos de dårIigst uddannede befolkningsgrupper, og en presselov, der skærpede ansvaret for forskellige presseforbrydelser - især imod statens sikkerhed og selvstændighed.

Også disse lovforslag blev omredigeret gennem gentagne behandlinger i Rigsdagen. Skoleloven gennemf $\phi r t e s$ f $\phi$ rst 18 . maj 1937. Presseloven og de deraf følgende konsekvensændringer af straffe- og retsplejeloven først 13. marts 1938.

Til gengæld udnyttede regeringen sin magt til ad administrativ vej at styrke den statslige informationsvirksomhed. Vigtigst blandt de mange tiltag var den $\phi g e d e$ annoncering $i$ dagspressen og oprettelsen af en række statskontrollerede serviceorganer, f.eks. Valutacentralens Pressebureau (1935), Statens Husholdningsråd (1935), Rådet for Større Færdselssikkerhed (1937), statens Annonce- og Reklamebureau (1937) og Statens Filmcentral (1939).

Set $i$ sammenhæng med regeringens sikre flertal efter 1937 og den zndrede beslutningsproces, hvor stadig flere beslutninger blev truffet bag lukkede døre uden for Folketinget, hævder presseforskeren Svend Thorsen, at man under krisen reelt havde sat offentligheden ud af spillet: ${ }^{30}$ )

"Vigtige samfundsanliggender flyttedes over på en ikkeoffentlig Debat, over til ikke-offentlig Afgørelse mellem de store Erhvervsorganisationer og Partiernes Repræ-

30) Sven Thorsen, op.cit. II, pp. $117 f$. 
sentanter i Forbindelse med Statens Embedsmænd... Forhandlingernes Resultat meddeltes som en Kendtsgerning, der vel undertiden drøftedes paa Rigsdagen, men hvorved der sjældent kunne ændres,... saa offentligheden (kom) i den situation, at den ikke kunne fremsætte sin Mening, d.v.s. varetage sine Interesser, medens Arbejdet endnu stod paa; man matte lade sig nøje med Forordninger."

Først med den tyske besattelse $i 1940$ suspenderedes den borgerlige offentlighed imidlertid formelt, idet der herefter gennemførtes en fuldstændig styring af informationsformidlingen.

De forste år blev forcensuren varetaget af Udenrigsministeriets Pressebureau, der dagligt udsendte instrukser med forbud mod omtale af bestemte emner. Dagspressen nedsatte desuden et Pressenævn; der kollegialt afgjorde, om der skete overtrædelser af forbudene. I alt rejstes fra tysk og dansk side 120 sadanne sager, og Pressenævnet dømte bod $i \quad 64$ tilfalde. Desuden blev $t i$ journalister og redakt $\varnothing$ rer fyret fra deres blade efter krav fra besættelsesmagten. 31 )

Efter den 28. august 1943 overtog tyskerne censuren, hvorefter alt politisk presse-stof blev gennemlæst. Besættelsesmagten udstedte herudover instrukser om opsætning af stoffet og pålagde medierne at bringe sarlige propaganda-meddelelser.

Valutacentralens pressebureau fik udvidet sin medarbejderstab og blev henlagt under statsministeriet under navnet Ministeriernes Pressebureau. Bureauet havde et budget på ca. 50.000 $\mathrm{kr}$. årligt, der bl,a. anvendtes til massiv annoncering $i$ dagspressen. Desuden varetog Justitsministeriets Propagandaudvalg ${ }^{32}$ ) en række mere generelle oplysningskampagner vedrørende energibesparelser og genbrug af răvarer.

$1945-1958$

Efter krigen ønskede Socialdemokratiet, at de midlertidige PR-organer blev opretholdt, og at staten fik sine egne trykkefaciliteter.

Men ligesom efter 1 . Verdenskrig lød der fra de borgerlige partier stærke protester imod administrationens ekspansion

31) Hvem Hvad Hvor 1964 , pp. $370 \mathrm{f}$.

32) Justitsministeriets Propagandaudvalg blev nedsat i 1940 og bestod af repræsentanter for Rådet for større Færdselssikkerhed, Statens Civile Luftværn og Dansk Brandværnskomitë. 
og krav om besparelser på informationsområdet. PR-organerne blev derfor nedlagt $i$ 1945, og af besparelseshensyn oprettedes Statens Tryksagskontor ved $\mathrm{kgl}$. resolution af 1.2. 1948. Kontoret skulle dog ikke selv producere statens informationsmateriale, men blot koordinere distribution og indk $\left.\varnothing b .{ }^{33}\right)$

Debatten $i$ de første efterkrigsår prægedes af фnsket om større åbenhed omkring statsforvaltningen og udvidelse af retssikkerhedsgarantierne. Både i Forfatningskommissionen af 1946 og Forvaltningskommissionen af 1947 drøftede man forslag til indf $\varnothing-$ relse af offentlighed $i$ forvaltningen, men bl.a. som følge af modstand fra Socialdemokratiet og embedsmændene konkluderede et kommissionsflertal i 1950, at ${ }^{34)}$

"det danske ministerialsystem med det dertil knyttede ansvar for ministrene for administrative afgфrelser $g \phi r$ en principiel og generel udvidelse af offentlighedens adgang til kendskab til forvaltningsakter upåkrævet, ja ubetimelig... (og) vil medføre afgørende ulemper og tvivlsomme fordele."

I sin afvisning af offentlighed $i$ forvaltningen, som den f.eks. fandtes $i$ Sverige, henviste kommissionsflertallet desuden til folketingets ombudsmand, der tråte $i$ funktion $i 1954$ og kunne varetage de onskede kontrolfunktioner, samt til lov af 2. februar 1866 , der sikrede en vis aktindsigt for ansфgere og klagere, efter en administrativ beslutning var truffet. Man foreslog, at denne lov eventuelt kunne revideres, hvilket $i 1956$ førte til nedsattelse af endnu en kommission. ${ }^{35}$ )

Det samlede resultat af bestræbelserne blev en videref $\varnothing-$ relse af et modereret oplysningsprincip, som bl.a. betød, at den statslige annoncering blev reduceret. Samtidig blev den private dagspresse hådt ramt af udefra kommende prisstigninger på papir og andre råvarer, hvilket resulterede $i$ en omfattende "bladdød". Følgen var fireblads-systemets endeligt, hvorefter de statsbærende partier nu ikke længere kunne regne med overalt at få deres interesser varetaget gennem en ustyret offentlighedsstrategi $i$ informationspolitikken.

33) Betankning afgivet af statens Papir- og Trykningsudvalg, Kbh. $\overline{1945 . ~}$

34) 7. Betænkning fra Forvaltningskommissionen af 1947, Kbh. 1950, p. 28 .

35) Betankning 325-1963 om offentlighed i forvaltningen. 
At man således på trods af efterkrigstidens almindelige velvilje alligevel, i begyndelsen af 1950'erne matte opgive at indføre et offentlighedsprincip i statsadministrationen, må ses på baggrund af den ændrede pressestruktur og de spandte $\phi$ konomiske og politiske forhold i perioden. Det drejede sig først og fremmest om at sikre arbejdsro omkring det reprasentative demokrati, og der var kun begranset plads til demokratiske eksperimenter $i$ informationspolitikken.

$\underline{1958-1973}$

Med konsolideringen af фkonomien i slutningen af 1950'erne blev der storre spillerum for politiske reformer. Af betyaning for informationspolitikken er bl.a. den nye uddannelsespolitik, der understregede betydningen af befolkningens aktive medvirken i beslutningsprocesserne. Næsten alle politiske partier anførte i 1960'erne, at staten $i$ sin informationsformidling burde tilstrabe en kommunikationsstrategi, d.v.s. fremme to-vejskommunikation mellem myndigheder og borgere, for derigennem at skabe større folkelig deltagelse $i$ politikken, jvf. et slagord som "nærdemokrati".

I praksis slog denne strategi imidlertid kun igennem i begrænset omfang. I 1964 gennemførtes en lov om partsoffentlighed, der udvidede mulighederne for borgerne til at opnå aktindsigt $i$ egne sager, men et flertal stottet af regeringen (Socialdemokratiet) afviste endnu en gang at indføre et almindeligt princip om offentlighed $i$ forvaltningen. ${ }^{36)}$

VKR pressede som opposition på for at gennemføre et sådant princip, bl.a. ved at fremsatte et privat lovforslag herom 2.11 . 1967. Forslaget naede dog ikke at blive færdigbehandlet på grund af nyvalg, og efter valget havde den nye regering (VKR) ikke lan-

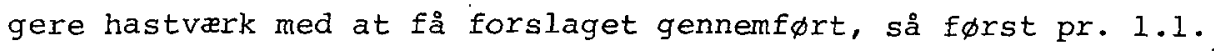
1971 tråte princippet om offentlighed $i$ forvaltningen i kraft. 37 ) Hermed var et nфdvendigt formelt grundlag for folkelig deltagelse $i$ de administrative processer tilvejebragt. På grund af

36) Ibid., pp. $42 \mathrm{E}$.

37) Jvf. Lov om offentlighed i forvaltningen af 10.6.1970. 
forslagets mange undtagelsesbestemmelser og dårlig oplysning af befolkningen om lovens eksistens fik offentlighedsprincippet imidlertid kun praktisk betydning for pressen, der $i$ forvejen havde uformel adgang til de fleste sager. Samtidig afviste Folketingets flertal forslag om bedre ytringsmuligheder i relation til statsforvaltningen, f.eks. $i$ forbindelse med behandlingen af venstresocialisternes forslag om en folketingsavis $i 1970$ og de konservatives forslag om en egentlig forvaltningslov i 1972.38)

Det var heller ikke primært hensynet til befolkningens politiske deltagelse, der i 1965 medførte, at man for første gang gennem et kommissionsarbejde mere systematisk s $\phi$ gte at kortlægge statens informationsvirksomhed. ${ }^{39)}$ Dette "lovtidendeudvalg" skuIle alene unders $\phi g e$ mulighederne for at give offentligheden bedre orientering om den voksende mængde af love og retsforskrifter, d.v.s. arbejde ud fra et oplysningsprincip.

Kommissionsarbejdet må ses på baggrund af de store фkonomiske problemer $i$ dagspressen $i$ disse år. ${ }^{40)} 5.9 .1966$ rettede Danske Dagblades Fællesrepræsentation således en henvendelse til statsministeren om udvidet offentlig annoncering $i$ dagspressen og andre former for indirekte фkonomisk hjælp til den kriseramte trykte presse, hvilket medførte, at regeringen nedsatte et såkaldt "uvildigt udvalg" til belysning af dagspressens struktur og $\phi k o-$ nomi. 4l)

Begge disse informationspolitiske udvalg sammenkædede i deres betænkninger spфrgsmålet om forbedret statslig information med indirekte støtte til dagspressen. Man indskrænkede sig stort

38) Se Folketingets Forhandlinger 1969/70, sp. 4044-4065 og Folketingets Forhandlinger 1972/73, sp. 1663ff. I regeringens af visning henvises bl.a. til det kommissionsarbejde, der i perioden 1963-1972 resulterer i Betænkning 657-1972 om begrundelse af forvaltningsafgørelser og administrativ rekurs.

39) Dette udvalg vedr. trykning af Lovtidende, Folketingstidende m.v. barsler med Betænkning 469-1967 om statens informationsvirksomhed, Betænkning 682-1973 om kundgørelse og opfyldelse af traktater og Betænkning 740-1975 om Lovtidende og Ministerialtidende.

40) Jvf. Den grafiske højskoles årlige bedriftssammenligninger af pressens фkonomi.

41) Betænkning 536-1969 om dagspressen og samfundet; betænkning vedr. udviklingen i dansk dagspresses struktur og фkonomi. 
set til at anbefale en rationalisering af statens publiceringsvirksomhed, en bedre udformning af love m.v., mere effektiv oplysning af interesseorganisationer og andre professionelle kommunikatorex, f.eks. advokater og erhvervsorganisationer, samt det $\phi n s k e-$ lige $i$ gget annoncering $i$ dagbladene. Derimod blev der - i modsætning til samtidige svenske udredninger ${ }^{42)}$ - kun $i$ meget begrænset omfang peget på foranstaltninger, der kunne indfri de politiske partiers angivelige intentioner om to-vejs kommunikation mellem stat og borger.

Det eneste konkrete, der kom ud af disse kommissionsbehandlinger, var nedsættelse af endnu en kommission, denne gang med det offentliges annoncering $i$ dagspressen som kommissorium. ${ }^{43}$ ) Kommissionen foreslog bl.a., at Statens Annonce- og Reklamekontor, der var blevet oprettet $i$ 1937, omdannedes til et egentligt administrativt informations-organ. Dette fandt dog ikke politisk stфtte på dette tidspunkt, hvorimod $\varnothing$ konomiministeriet med udgangspunkt $i$ betænkningen udformede et cirkulære om statslige myndigheders annoncering og reklamering af 3. november 1972 .

Den til cirkulæret medfølgende vejledning om offentlig annoncering, der stadig er gældende, fastslår, at staten ved informativ reklamering skal indrykke annoncer i samtlige danske aviser, hvorimod myndighederne stilles frit m.h.t. administrative annoncer, f.eks. stillingsopslag og licitationer.

De første fors $\varnothing$ g med informative annoncekampagner $i$ fredstid lanceredes $i$ 1969-70 ved indførelsen af kildeskatten og lov om by- og landzoner. Desuden indhøstede partierne erfaringer med udvidet statslig information $i$ forbindelse med kampagnen op til folkeafstemningen om dansk medlemskab af EF.

Når der imidlertid heller ikke i 1960'erne og begyndelsen af 1970'erne skete nogen fundamental omlægning af statens informationsvirkșomhed på trods af den intensive debat, skyldtes det

42) Den svenske hovedbetænkning er SOU 1969:38 "Vidgad samhällsinformation". Desuden kan nævnes SOU 1967:5 "Statslig publicering", SOU 1967:7 "Kundgörelsesannonsering" og SOU 1972:52 "Rapport angående kommunal information $\mathrm{m}$ ".

43) Jvf. Betænkning 641-1972 afgivet af det af statsministeren 31.7 .1970 nedsatte udvalg vedr. det offentliges annoncering $i$ dagspressen. 
bl.a. forskellige præferencer i spørgsmalet om presse-st $\varnothing t t e$, hvor Socialdemokratiet var indstillet på en selektiv stotte, mens VKR helst så en ensartet og indirekte støtte. Desuden må den tilsyneladende rådvildhed $i$ informationspolitikken ses $i$ forhold til andre modstående politiske hensyn, f.eks. ønsker om begrænsning i. statsapparatets vækst, ${ }^{44)}$ hensynet til privatiivets fred ${ }^{45}$ ) og negative erfaringer med en aktiv statslig politik på den kulturelle offentligheds omrade. ${ }^{46)}$

$$
\text { Kun i Danmarks Radio }{ }^{47} \text { og } i \text { lokaladministrationen } 48 \text { ) }
$$

eksperimenteredes der i praksis med politisk kommunikation, hvilket dog for sidstnævntes vedkommende næppe kan betegnes som en faktisk udvidelse af den folkelige participation, idet bestræbelserne $i$ retning af formaliseret borgerdeltagelse skete samtidig med kommunalreformens centralisering, der svakkede tidligere tiders uformelle lokalkommunikation.

\section{Perioden efter 1973}

Først da en voksende politisk utilfredshed direkte kunne aflæses $i$ opinionsinstitutternes meningsmålinger, fandt de fire "gamle" partier sammen om at gфre noget ved informationsproblemerne, jvf. Hilmar Baunsgaards udtalelse til Weekendavisen 7.9. 1973:

44) Se f.eks. forslag om nedsættelse af et udvalg til rationalisering af statsadministrationen, Folketingstidende 1967/68 A 1387, B 1569 og C 37.

45) I folketingsårene 1967/68 og 1968/69 fremkommer flere forslag til sikring af privatlivets fred, bl.a. fra Det radikale Venstre, SF og VS, og 12.5.1967 anmoder justitsministeren straffelovsrådet om et responsum om spørgsmalet, jvf. Betankning 6011971.

46) Jvf. debatten om kulturstøtten, legalisering af pornografi og den såkaldte "indoktrineringsdebat". Se f.eks. Lise Togeby, "Indoktrineringsdebattens historie" i Historien om folkesko-

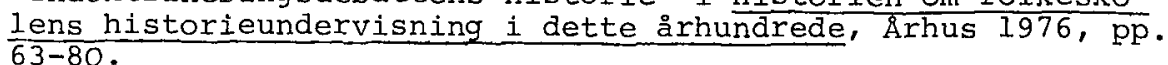

47) Anker Brink Lund, op.cit., pp. 59-93.

48) Georg Gottschalk og Jens Chr. Tonboe, Offentlighed, hemmelighed og medindflydelse i planlagningen (bind 2), Kbh. 1975, jvf. Betænkning 798-1977 om kommunalt nærdemokrati, pp. 9-16. 


\begin{abstract}
"Der er nu stor forståelse for problemet. Politikere - og det fra alle partier - har det sidste års tid mærket en voldsom negativ reaktion $i$ befolkningen. Vi er blevet klar over, at der er en kommunikationskløft... Som oppositionspolitiker vil jeg $i$ dag gå ind for, at det offentlige $i$ meget $h \phi j$ grad informerer befolkningen. Det er af fælles interesse, at der bliver informeret. Borgernes konstaterede utilfredshed med den politiske indsats rammer jo $i$ lige $h \phi j$ grad regeringen og oppositionen. Derfor som næunt den større forståelse for informationspligten."
\end{abstract}

Der er to væsentlige momenter $i$ denne udtalelse: For det første er 1960'ernes ideal om en ustyret to-vejs kommunikation i informationspolitikken udskiftet med et eksplicit ønske om en oplysningsstrategi. For det andet understreger nu både regering og opposition behovet for styret information.

Valget $i$ december 1973, der bet $\phi d$ reprasentation af Fremskridtspartiet og andre "protest-partier" $i$ folketinget, cementerede denne konsensus. Desuden gav "oliekrisen" stødet til en stor administrativ informationskampagne. Koordineret af Handelsministeriets Energispareudvalg og formidlet gennem et privat reklamebureau anvendtes alene $i$ finansåret 1973/74 3,7 mill. kr. på oplysning om energiforhold. Hertil kom, at flere partier i marts 1974 søgte at forklare befolkningen baggrunden for en række politiske indgreb gennem dagbladsannoncer, hvilket var første gang, politikerne valgte en sådan fremgangsmåde uden for de egentlige valgkampe.

En række arbejdsgrupper og kommissioner arbejdede $i$ centraladministrationen med informationsproblemerne. Enkelte ministerier og styrelser fik normeret informationsmedarbejdere, og Folketinget ansatte $i 1974$ en pressechef på fors $\phi g s b a s i s$. I første omgang skete der dog ikke i statslig regi nogen samlet afklaring af oplysningsstrategien, hvorimod de berørte brancher tog en række private initiativer, der havde til formal at presse staten til at føre en udvidet og mere bevidst informationspolitik.

Dagspressen, der ramtes hårdt af stigningerne i olie- og papirpriserne samt fald $i$ annonce-porteføljen, fremsatte gentagne gange krav om $\phi$ get pressest $\phi t t e,{ }^{49)}$ og $i$ reklamebranchen dannedes

49) Om den eksisterende pressest $\varnothing$ tte og forslag til udvidelse heraf se Redegørelse fra arbejdsgruppen vedr. statens forhold til dagspressen m.v. fra statsministeriet (november 1976) og ole John Poulsen, Stat og presse - et bidrag til en pressepolitik, Århus 1976. 
i efteråret 1973 den såkaldte Relationsgruppe, der i januar 1975 indkaldte en omfattende kreds af politikere, administratorer, reklamefolk og redaktører til et seminar om statslig information. ${ }^{50)}$

Seminaret mundede ikke ud $i$ et konkret forslag,' men gav i sin rapport udtryk for en almindelig accept af, at der eksisterer en statslig og kommunal informationspligt. Indlægene prægedes bl.a. af Folketingets ombudsmand Lars Nordskov Nielsen, der allerede ved et foredrag $i$ det private selskab for samfundsdebat og siden $i$ dagbladskronikker ${ }^{51}$ havde markeret sig som fortaler for фget statslig oplysning. Organisatorisk fremhævedes nogle synspunkter, der bl.a. var formuleret af direktør.M. Kaarøe fra Danske Dagblades Udgiverforening i Politikens kronik 7.8.1974:

"Den offentlige information må gennemføres efter den model, der er skabt af moderne markedsf $\phi$ ring $i$ erhvervslivet... Man skal ikke forestille sig, at det bor tilrades at udbygge det eksisterende reklamekontor til en ny omfattende statsinstitution med masser af medarbejdere og et stort bureaukratisk apparat. Det er ikke nфdvendigt: Det der tiltrænges, er en ny målsætning for dette kontor (som dækkes af et nyt navn) og udbygning af et fornuftigt og tilfredsstillende samarbejde med den danske reklamebranche."

Muligheden for en sådan løsning opstod, da den hidtidige leder af Statens Annonce- og Reklamekontor blev pensioneret, og en plan. efter disse retningslinier blev $i$ juni 1975 offentliggjort af Administrationsdepartementet: ${ }^{52)}$ Annoncekontoret omd $\phi$ btes statens Informationskontor og $f i k$ udvidede beføjelser og opgaver, men kun begrænsede $\varnothing$ konomiske og mandskabsmæssige ressourcer. Stillingen som statens Informationsdirekt $\varnothing \mathrm{r}$ besattes med TV-speakeren Henning skaarup, der tiltrådte 1. november 1975.

Omorganiseringen havde ikke varet forelagt Folketingets plenum. I første omgang fastlagde lovgivningsmagten derfor ikke

50) Relationsgruppen bestar af Harlang, Toksvig \& STB Reklamebureau AS, Rådgivende Sociologer AS og fa. Relationskonsulent og er $i$ dag den mest benyttede kanal for statslige informationskampagner. Deltagerlisten og diskussionen er refereret i Rapporten fra seminaret om statslig information, Kbh. 1975.

51) Foredraget er aftrykt $i$ den $i$ note 50 næunte rapport og $i$ en dobbeltkronik i Politiken 14. og 15.10.1974.

52) Finansministeriets cirkulære nr. 100 af 12. juni 1975. 
nærmere retningslinier for kontorets virksomhed og målsætning. Men som en indirekte udløber af et møde mellem Folketingets erhvervsudvalg, statsministeren og pressens organisationer på Marienborg 16.10.1975 om pressest $\phi$ tte fremsatte Venstre og Det radikale Venstre $i$ december 1975 et forslag til folketingsbeslutning, hvori det bl.a. hed: $\left.{ }^{53}\right)$

"Folketinget opfordrer regeringen til at nedsatte et udvalg på 11 medlemmer til udformning af regler for en udvidet statslig information... Inden 1. april 1976 skal udvalget udforme regler for indhold og omfang af en udvidet statslig information om bl.a. vedtagne lovforslag, bekendtgørelser, andringer i cirkulærer m.v. Informationen skal fortrinsvis ske gennem avertering i dagblade..."

De fleste partier i Folketinget tog velvilligt imod forslaget. Dog păpegede oppositions-ordførerne risikoen for propaganda for den siddende regering, ligesom der ved forslagets vedtagelse 9. april 1975 som en indrommelse til socialdemokratiet blev vedtaget en andring $i$ ordlyden, der fremhævede radio og TV og nedspillede pressest $\varnothing$ teaspektet. ${ }^{54}$ )

Det nedsatte informationsudvalg, der fik ombudsmanden Lars Nordskov Nielsen som formand og domineredes af de partipolitiske medlemmer, konkluderede, ${ }^{55}$ at statens Informationskontor måte styrkes mandskabs- og bevillingsmæssigt, og fulgtei øvrigt de retningslinier, Informationsdirekt $\phi$ ren havde afstukket for sin virksomhed. 56)

Ved et regeringsm $\varnothing$ de 15. marts 1977 bebudede regeringen, at den var indstillet på at føre udvalgets intentioner ud i livet. I den mellemliggende tid havde statens Informationskontor allerede markeret sig bl.a. gennem kampagner omkring den nye folkeskolelov, regeringens 1976-budget og indførelsen af den sociale bistandslov. Desuden blev der bebudet en omlægning af statstidende, en sammenlægning af Lov- og Ministerialtidende, og den 5. april 1976 ind-

53) Folketingstidende 1975/76, forslag $\mathrm{nr}$. XLIV.

54) Folketingets Forhandlinger 1975/76 (fortryk), sp. 8511-8516.

55) Betænkning $\mathrm{nr} .787$ om udvidet statslig information om love m.v.

56) Jvf. Statens Informationskontors redegфrelse til Lønningsrådet aftrykt som bilag til finansudvalgets aktstykke 515 af 13.8 .1975 . 
vilgede Danmarks Radio $i$ at stille sendetid til rådighed for statsstyret information i radio og $\mathrm{TV}$, hvorved vejen synes banet for skabelsen af en mere aktiv og institutionaliseret informationspolitik $i$ de kommende $\stackrel{\mathrm{r}}{\mathrm{5}}{ }^{57}$ )

\section{Informationsvirksomhedens funktioner i 1970'erne}

sammenfattende kan det om udviklingen $i$ statens informationsvirksomhed konkluderes, at man $i$ Danmark fra en oplysningsstrategi under enevældens sidste år har haft en periode, hvor offentlighedsprincippet og onsket om ustyret informationsformidling har været dominerende for så igen $i$ de seneste år at vende tilbage til en mere statsstyret oplysningsstrategi.

Man kan imidlertid ikke med Jürgen Habermas tale om en egentlig "refeudalisering" af den politiske offentlighed. ${ }^{58}$ ) For det første er der $i$ dag tale om en anden samfundsformation og en mere effektiv informationsteknik. Den statslige administration og medierne er udbygget $i$ et omfang, man ikke kendte i 1800-tallet. For det andet er udviklingen ikke forløbet jævnt, men derimod modsætningsfyldt og $i$ spring. Nærmest ved at være gennemført er offentlighedsprincippet $i$ perioden fra systemskiftet frem til 1. Verdenskrig. Men den liberalistiske idé om borgerlig offentlighed er ingen fuldkommen realitet heller ikke $i$ denne periode. Endelig - for det tredje - $g \phi r$ der sig i den konkrete danske udvikling en række faktorer $g æ l d e n d e$, der umuligg $\not x$ en direkte applicering af Habermas' udviklingsmodel, der især bygger på forholdene i England. Vigtigst er, at bærerne af den tidlige liberale offentlighed $i$ Darmark er et embedsmandsdomineret "stedfortrædende borgerskab", og at offentlighedsidealet siden overtages af gårdmands-klassen, der omformer det til et ideal om en parlamentarisk parti-offentlighed.

57) Der findes ingen samlet opgørelse over statens nuværende udgifter til informationsvirksomheden, og mulighederne for at danne sig et overblik vanskeliggøres ved, at udgifterne til de enkelte emner opgøres pa de forskellige styrelses-konti. Om det fremtidige behov anfører statens Informationskontor budgetterne for Norge og Sverige, hvor der $i \quad 1975 / 76$ blev anvendt hhv. $35 \mathrm{mill}$. og $52 \mathrm{mill}$. $\mathrm{kr}$. til annoncering og information om love og andre retsforskrifter, jvf. Betænkning 787, p. 106.

58) Jürgen Habermas, op.cit., pp. 169-221. 
Derimod kan udviklingen beskrives således, at man i Danmark $i$ perioden med jævn vækst og relativ politisk sabilitet har arbejdet ud fra en liberal informationsideologi, d.v.s. at man $i$ statsstyrelsen har tilstrabt et offentlighedsprincip, hvor informationsarbejdet $s \varnothing g e s$ overladt til den enkelte borger og pressen som "den kontrollerende 4. statsmagt", mens myndighederne i perioder med krise og social uro har hyldet en socialansvars-ideologi, d.v.s. opdyrket et oplysningsprincip og søgt at styre informationsudbuddet gennem aktiv indsats i relation til pressen og andre dele af samfundsstrukturen, f.eks. under forfatningskampen $i$ slutningen af 1800-tallet, under krigene og i 1930'ernes фkonomiske krise. ${ }^{59)}$

Også i 1970'erne ex der krise i samfundsstrukturen. Ganske vist slår krisetendenserne først igennem på det фkonomiske niveau som generel konjunkturafmatning og massearbejdsløshed efter vinteren 1973-74. Men allerede i slutningen af 1960'erne spores recessionen $i$ enkekte brancher og en voksende usikkerhed både $i$ Danmark og $i$ udlandet med hensyn til grundlaget for væksten $i$ "industrisamfundet".

"Ungdomsoprør", forureningsdebat, krav om nedskæringer $i$ de offentlige udgifter, protester mod det voksende skattetryk, hyppige valg og partidannelser med populistiske protest-programmer markerer det, forskere har betegnet som det borgerlige demokratis strukturelle legitimationskrise. 60)

Formelt baserer det borgerlige demokrati sig på kontinuerlig rationalitet og folkelig tilslutning, id́et statsorganerne konstitueres gennem valg, og politiske beslutninger bliver legitime ved, at de valgte repræsentanter følger bestemte grundlovssikrede procedurer.

59) Et tredje element, kommunikationsprincippet og participationsideologien, er fremme en kort periode under 1960'ernes højkonjunktur, men satter sig ingen konkrete spor i udviklingen. Om informationsideologierne se $i$ ovrigt F. Siebert, T. Peterson \& W. Schram, Four Theories of the Press, Urbana 1972.

60) Se f.eks. Johannes Angeli, therleguncen zum bürgerlichen Staat, Wemding 1975, Rolf Ebbighausen (Hrg.), Bürgerlicher Stat und politische Legitimation, Nordlingen 1976, Jïrgen Habermas, Legitimationsproblemer i senkapitalismen, Kbh. 1975 og Hors Holzer, Kommunikationssoziologie, Frankfurt/M 1974. 
Den borgerlige offentligheds "forfald", der er forărsaget af ændringer $i$ produktionsstrukturen, manifesterer sig $i$ andrede politiske procedurer, f.eks. tendenser mod lukkede politiske forlig frem for åben diskussion i Folketinget, flere fuldmagtslove og delegation, mere indflydelse til (sær)interesseorganisationerne og en voksende offentlig sektor.

Det betyder, at legitimationsbehovet $\phi$ ges, idet den tiltagende statsintervention $i$ den private sektor, korporatismen og det voksende skattetryk, der ex objektivt nødvendigt for opretholdelsen af den eksisterende samfundsorden, af store dele af befolkningen opfattes som subjektivt stridende imod den herskende samfundsopfattelse, f.eks. som en sammenblariing af den private og offentlige sfære.

Der opstår troværdighedskløfter mellem de repræsenterede og de repræsenterende (samt den bagvedliggende magtbasis). Beslutningernes legitimitet og rationalitet drages i tvivl, hvorved der opstår fare for, at politiske beslutninger ikke opfattes som magtneutrale almeninteresser, hvilket igen medfører risiko for manglende folkelig tilslutning, f.eks. ved at befolkningsgrupper bl.a. gennem kapitalflugt eller "vilde" strejker saboterer samfundssystemet eller undlader at rette sig efter love m.v.

\subsection{Legitimationshjælp}

Det er derfor narliggende som hypotese at anf $\phi$ re behovet for фget legitimation af styreformen som en af den udvidede informationsvirksomheds centrale funktioner.

Også $i$ de eksplicitte motiver anes sådanne hensyn, jvf. f.eks. informationsudvalgets betragtninger om informationsvirksomhedens målsætning: ${ }^{61)}$

"En effektiv informationsvirksomhed om love m.v. har en tilstrækkelig begrundelse i menneskets etiske krav på at være velinformeret om deres retsstilling. Udvalgsflertallet fremhæver i $\phi v r i g t$,

at en god information om lovgivning $\mathrm{m} . \mathrm{v}$. er forudsatningen for, at den pågældende lovgivnings politiske målsætning kan realiseres,

at information kan være et middel til begrænsning af administration og til rationalisering af administrative procedurer,

61) Betankning 787-1977, p. 60 . 
at en vel tilrettelagt informationsvirksomhed kan bidrage til at mindske den eksisterende ulighed mellem befolkningsgrupper, der er en følge af de nuværende forskelle $i$ information.

Herudover fremhæver udvalgsflertallet, at $\phi$ get information kan bidrage til en bedre forstålse mellem mennesker og myndigheder og skabe et bedre grundlag for en rimelig funderet - positiv eller negativ - vurdering af de offentlige myndigheders indsats."

Bag disse motiver ligger en formodning om, at statens legitimationsunderskud kan afbødes gennem udfyldning af den såkaldte "informationskløft". Synspunktet uddybes af informationsudvalgets formand $i$ en kommentar til betænkningen: ${ }^{62}$ )

"En bedre information kan bidrage til mange ting. Det er ikke alene et spørgsmål om, at folk får bedre mulighed for at varetage deres retlige interesser, men gennem en sadan information kan man bidrage til en anden holdning til myndighederne. Folk tranger til at vide mere om, hvad det offentlige egentlig går og laver... Jeg er personlig sikker på, at mange menneskers negative holdning over for de offentlige myndigheder hænger sammen med, at de en gang om àret făr at vide, hvad de skal betale - selvangivelsen. Der gives ikke nogen rimelig information om, hvad de far for deres penge."

En $\phi g e t ~ s t a t s l i g$ information kan således tjene til at skabe $\phi$ get folkelig loyalitet omkring den herskende sociale orden. Ganske vist understreger betænkningen, at der skal være mulighed for såvel negativ som positiv stillingtagen. Imidlertid tyder den hidtidige praksis pa, at statsstyret information nфdvendigvis vil understrege det positive, idet udgangspunktet for informationen er vedtagelser $i$ de kompetende myndigheder, hvilket pr. definition betyder, at beslutningerne har fåt det parlamentariske "blå stempel" og dermed er lige med samfundets almeninteresser - uanset om et forslag er vedtaget enstemigt eller kun med en enkelt stemmes overvagt. Statslig information skal eksempelvis ikke redeg $\varnothing \mathrm{re}$ for beslutningsprocessen eller fortolke tvivlsspørgsmål, men må gerne redegøre for motiverne bag et vedtaget statsligt tiltag. 63 )

62) Lars Nordskov Nielsen til AC-debat 3-77, p. 39.

63) Økonomi- og buagetministeriets vejledning nr. 238 af 3 . november 1972. punkt II.4, jvf. Betankning 787-1977, p. 51. 
Informationskontorets intentioner med hensyn til, hvilke typer love der bør informeres mere om, 64) tyder også på, at man vil fremhæve det positive, hvorimod man næppe kan forvente en kampagne, der går på temaet: "Her er en lovændring, der på de og de punkter betyder en forringelse af den hidtidige tilstand", f.eks. med hensyn til sociale ydelser.

Ligeledes vil de anvendte reklameteknikker tendere mod at fremhæve ændringer, som af modtageren opfattes som noget nyt (og bedre). Tydeligst ses det $i$ kampagnen om bistandsloven fra foråret 1976: Lovkomplekset gav ikke nogen materiel udvidelse af bistandsmulighederne, men var blot en samling af dellove, der allerede var gældende. Samtidig (gen) indførtes skønsprincippet, og kompetencen blev udlagt til kommuner og amter, hvilket fra sagkyndig side vurderes sadan, at det set i sammenhang med besparelserne på de offentlige budgetter sandsynligvis vil betyde en direkte forringelse af servicemulighederne for en del klient-gruppers vedkommende. I annoncer, pjecer og radio-TV opregnede socialministeriet, der ledede kampagnen sammen med statens Informationskontor, imidlertid især de eksisterende støttemuligheder og understregede, at systemet indebar fordele for alle, at det var en forenkling og en lettere vej til bistand. At informationsmodtagerne opfattede det således, at der var tale om en reel udvidelse af bistandsmulighederne, fremgik bl.a. af de mange, som efter kampagnen gik forgæves til socialkontorerne for at få hjælp. ${ }^{66)}$

64) Statens Informationskontor, "Liste over love, man kunne have informeret om $i$ perioden 1. juli 1975 - 30. juni 1976, samt love, der er informeret om, men hvor man kunne have overvejet yderligere information" (uoptrykt underbilag til bilag 5 i Betankning 787-1977, p. 106). Statens Informationskontor gør opmarksom på, at listen ikke ex autoritativ, men tendensen synes klar, bl.a. set i sammenhæng med de faktiske danske kampagner og de svenske erfaringer, jvf. Ekecrantz, op.cit., pp. 87-98.

66) Jvf. et rundspørge til bistandskontorerne foretaget af Danske Kommuner $\mathrm{nr} \cdot 10-1976$, pp. 4-16. 
Disse konsekvenser er næppe tilsigtede fra statens Informationskontors side, men er vanskelige at undgå i praksis. Vi savner endnu offentliggjorte effekt-forskning på de danske kampagner, men erfaringer fra udlandet, bl.a. Sverige og sovjetunionen, hvor man er langt fremme med gennemføreise af et statsstyret oplysningsprincip, synes at vise, at kampagner $i$ befolkningen $n \varnothing d-$ vendigvis efterlader et indtryk af fremskridt og opslutning bag "den gode stat". Lars Nordskov Nielsen konstaterer således, at statens information "på trods af de bedste hensigter, altid vil få et element af noget reklameagtigt over sig". 67)

Et bi-produkt ved envejskommunikationen er desuden, at oplysningsvirksomheden ikke alene legitimerer styreformen og dens procedurer, men også giver $\mathrm{PR}$ for styret, den siddende regering og de bagvediliggende parti-interesser.

Allerede ved indførelsen af Statstidende $i 1903$ advarede oppositionen imod denne tendens, og ved de senere udvidelser af informationsvirksomheden har det som regel været regeringen, der har onsket en udvidelse, mens oppositionen har advaret mod propagandaeffekten. I 1970'erne findes modstanderne af udvidet statslig informationsvirksomhed tilsyneladende kun $i$ de partier, der Ønsker vidtgående ændringer af samfundsopbygningen, f.eks. Venstresocialisterne og Fremskridtspartiet, jvf. denne udtalelse fra Kjeld Wamberg (Frp): ${ }^{68}$ )

"En statslig informationstjeneste vil under nutidens forhold hovedsageligt være et propagandaapparat for den siddende regering og de partier, som har nogenlunde fælles grundlag med regeringen. De hidtidige danske fors $\phi g$ på at lade staten informere er $i$ så henseende afskrakkende. For eksempel rummede propagandak $\phi x s l e n$ for den sociale bistandslov $i$ foråret 1976 meget lidt af interesse for den sociale klient, men var forst og fremmest eet langt politisk indlæg til forsvar for den socialpolitiske grundholdning, der vil gä over i hsitorien som Eva Gredal-linien."

67) Citeret efter Rapporten fra seminaret om statsig information, Kbh. 1976, p. 25 . Om de svenske erfaringer se Harry Schein, Inför en ny mediapolitik, stockholm 1972, pp. 102-120.

68) Betænkning 787-1977, p. 58 . 
$\underline{2} \cdot 2$. Styring

Snævert forbundet med legitimationsproblematikken er det samfundsfænomen, man kunne betegne en "rationalitetskrise", d.v.s. en krise $i$ det administrative apparat, som følge af at staten $i$ en modsætningsfyldt samfundsformation ikke har sikre (og modsætningsfrie) styringsmekanismer til rådighed.

Informationens rolle $i$ denne sammenhæng understreges bl.a. $i$ den galdende vejledning om det offentiges brug af annoncering: ${ }^{69}$ )

"Bredt oplysende annoncering kan i særlige tilfælde udgøre et alternativ til gennemførelse af retsforskrifter eller administrative dispositioner, navnlig i form af forebyggende kampagner, der kan overflфdiggфre - muligvis væsentlige kostbarere - lovgivningsmæssige eller administrative foranstaltninger."

En sadan informationsindsats betegnes ofte som indoktrinering, 70 men da denne term $i$ dansk sprogbrug har faet stærkt negative konnotationer og ofte anvendes synonymt med termen propaganda, forekommer det mere hensigtsmassigt at tale om politisk styring, socalisering eller social kontrol. 71 )

Den generelle styring af befolkningens holdninger, normer og adfærd ses bl.a. i de store færdselskampagner og energisparekampagnerne. Et langt stykke vej er den sociale kontrol uproblematisk, men erfaringer fra Sverige viser, at man ofte bevæger sig ind på områder, hvor der ikke hersker almen konsensus on de pågældende normers almeninteresser, f.eks. abortspørgsmål, alkoholoplysning. m.v. I Danmark er statens Informationskontor klar over problemets eksistens, og informationsdirektøren har som et eksempel på en kampagne, kontoret ikke vil gennemføre, nævnt en eventuel beslutning om indførelse af dansk "Berufsverbot". 72

I modsætning til legitimationshjælpen er styringsfunktionen ikke kun rettet imod befolkningen som helhed, men også til enkelte samfundsgrupper med særlige karakteristika. Ofte er der

69) Økonomi- og budgetministeriets vejledning nr. 238 af 3 . november 1972, punkt I.4.

70) Jvf. Göran Palm, Indoktrineringen i Sverige, Stockh. 1968, og Pertti Hemanus, "Propaganda and Indoctrination: A Tentative Concept Analysis", Gasette Vol. XX, No. 4-1974, pp. 215-223.

71) Jvf. Marvin Olsen, The Process of Social Organization, N.Y. 1970, p. 118.

72) Henning Skaarup i " $+5 "$ i radioens $P 1,20.9 .1976$. 
tale om social kontrol med afvigere eller marginalt placerede borgere, f.eks. kriminelle, ${ }^{73)}$ og styringsproblemerne spiller også en rolle $i$ relation til de såkaldte "informationssvage" (se afsnit 2.3.).

Desuden er styringsfunktionen af stor betydning $i$ forhold til lokalforvaltningen, interesseorganisationerne og massemedierne, jvf. motiverne bag effektiviseringen af statstidende: ${ }^{74)}$

"Man vil herved opnå en effektivisering af informationen til de myndigheder m.v., der tjener som mellemled mellem folketinget, regeringen og centraladministrationen på den ene side og befolkningen på den anden side, en information, der er lige så vigtig som den direkte information af befolkningen."

Disse "transformationskanaler" betegnes ofte som ideologiske statsapparater, ${ }^{75}$ ) og det er karakteristisk for dem, at de har en st $\varnothing r-$ re autonomi end den hierarkisk opbyggede centralforvaltning.

Styringsproblemet er $i$ de seneste år blevet accentueret efter 1960'ernes bestrabelser på at gennemf $\varnothing$ re dekoncentration og decentralisering som modvægt til efterkrigstidens markante centraliseringstendens $i$ samfundet. Kommunalreformen har bl.a. betydet stфrre og mere uafhæingige kommunale enheder, der som følge af bloktilskuddene også har fået større фkonomisk autonomi. Bistandslovskampagnen kan ud fra dette synspunkt ses som et fors $\phi \mathrm{g}$ på fra Socialministeriets side at tvinge kommuner og amter til en ensartet praksis gennem direkte information til bistandskontorerne og indirekte information til pressen og $k l i e n t e r n e$.

Den $\varnothing$ gede centrale informationsvirksomhed kan således medvirke til $\varnothing$ get effektivitet og rationaliseringer $i$ administrationen. 76) Dog har man fra de styrelser, der selv har informationsmedarbejdere, advaret imod at opbygge et stort "omsvøbs-departement" $i$ centraladministrationen, og $i$ stedet foreslået at man sat-

73) Betænkning 714-1974 om Kriminalforsorgen og massemedierne.

74) Finansudvalgets aktstykke 515 af 13.8 .1975 og gentaget ordret i Betænkning 787-1977, p. 20 .

75) Louis Althusser, "Idéologie et appareils idéologiquies d'Etat. Note pour une Rechersche", Le Pensée 151-1970, pp. 3-38.

76) Se f.eks. Olaf Johansen, Rationalisering af statsadministrationen, Kbh. 1971, pp. 55 f. 
ser på styring af informationen $i$ de enkelte forvaltningsorganer.

En effektivisering af styringen kan også ske gennem indaragelse af interesseorganisationerne. Arbejdsretsjuristen Per Jacobsen pointerer således, at det han betegner som en krise for det arbejdsretlige system - og de dermed forbundne ulemper for den samfundsmæssige orden - kan afhjælpes gennem oget samfundsinformation til lфnarbejderne: ${ }^{78)}$

"En virkeligt professionelt tilrettelagt kampagne kunne utvivlsomt fa ganske positive virkninger. Om varen er vaskepulver eller arbejdsretlige regler er formentlig underordnet. En sådan kampagne kunne iværksættes af LO og dens underorganisationer, den kunne også iværksættes af de 2 hovedorganisationer i fallesskab. Det ville være en rimelig måde at anvende nogle af de betydelge midler, som organisationerne har opsamlet, på. Det kunne imidlertid også nok være en overvejelse værd, om en sådan opgave ikke burde iværksættes af samfundsmagten. Resultatet ville sikkert have en generel samfundsфkonomisk virkning."

I Sverige kanaliseres store dele af den statslige information gennem arbejdsmarkedsorganisationerne, ${ }^{79}$ ) og herhjemme findes et snævert samarbejde mellem staten og interesseorganisationerne på informationsomradet, bl.a. i henseende til miljø-og arbejderbeskyttelsessporgsmål. Med de voksende tendenser $i$ retning af korporatisme $i$ statsstyrelsen kan man forvente, at dette samarbejde vil blive udbygget, hvorved de private organisationer i stigende omfang kommer til at optræde som selvstændige informationsmodtagere og informationsfiltre til og fra medlemmerne.

omkring den information, der formidles gennem massemedierne, indgår et eksplicit фnske om oget styring og en effektivisering af indsatsen: ${ }^{80}$ )

"Det må anses for betydningsfuldt, at information bringes $i$ medier, hvor der kan etableres en rimelig forbindelse imellem selve den offentlige information (f.eks. en annonce) og en redaktionel behandling af det emne, informa-

77) Jørgen Nue Møller, Kormunernes Landsforening, i Rapporten fra Seminaret om statslig information, Kbh. 1975, p. 25 , jvf. Bo Maltesen, "Stop Skaarup på marchen mod 'informationsdepartementet'", Journalisten, nr. 7/8-1976, p. 15.

78) Per Jacobsen, "Krise for det arbejdsretlige system?", Juristen \& Økonomen, $\mathrm{nr} .5-1977, \mathrm{p} .108$.

79) Lowe Hedman, Selektiv information - På gott eller ont?, Bjerringbro 1975.

80) Betankning 787-1977, p. 38 . 
tionen vedrører, idet det må antages, at de to informationer (den redaktionelle og selve den offentlige information) kan styrke hinanden."

Bag dette synspunkt ligger tilsyneladende - foruden $\phi n s k e t$ om at støtte dagspressen på andre (ikke-redaktionelle) mediers bekostning - en mistillid til, at de private dagblade i tilstrækkeligt omfang kan varetage den politiske socialisering af befolkningen og derfor et фnske om mere statslig indflydelse på den redaktionelle linje.

Det kan forekomme mindre åbenbart, at der udtrykkes et tilsvarende $\varnothing n s k e$ om $\phi g g t$ statsstyring af samfundsinformationen via Danmarks Radio. Rtermedierne udg $\varnothing r$ jo i Danmark et semi-statsligt monopol, men baggrunden for direkte statslig produktion af radiospots og redaktion af et fast $\mathrm{TV}$-program o(rientering) $\mathrm{B}$ (orger S(amfund) må ses $i$ sammenhæng med den $\phi$ gede autonomi, som DR erhvervede $i$ 1960'erne. Også her er tendensen, at statsmagten $i$ 1970'erne intensiverer den centrale styring gennem informationsvirksomheden. 81 )

\subsection{Participation}

Anskuet fra de repræsenteredes side fremtræder legitimationsproblemerne som en "motivationskrise": $i$ og med de strukturelle zndringer $i$ den politiske offentlighed bliver det vanskeligere at fastholde borgernes interesse for systemet. De repræsenterede fremmedgøres og føler intet behov for at deltage $i$ de traditionelle aktiviteter $i$ det representative demokrati. For at fastholde borgernes tilslutning kan man derfor, bl.a. gennem informationspolitikken, søge at opmuntre til og udbygge mulighederne for involvering og deltagelse $i$ de politiske processer.

Ved participation forstås aile de former for aktiviteter den enkelte borger kan deltage $i$. Traditionelt har disse aktiviteter indskrænket sig til stemmeafgivning ved valg og medlemskab af politiske partier og interesseorganisationer. Men især $i$ 1960' ernes debat om kommunikationspolitikken indgår det som et væsentligt motiv, at søge det repræsentative demokrati udbygget med mere

81) On udviklingen i Danmarks Radio se Anker Brink Lund, op.cit., pp. 35-120. De konkrete regler for samfundsinformation i DR udformet af Programdirekt $\varnothing$ rembedet er optaget i Betænkning 7871977, p. 122 . 
direkte og utraditionelle participationsformer.

Kommunikationsforskere understreger, at participationen, hvis den skal bevæge sig ud over formel følelse af pseudoparticipation må skabe stфrre lighed blandt befolkningsgrupperne m.h.t. politiske ressourcer ${ }^{82}$ ) og begynde så tidligt i beslutningsprocessen, at der endnu ikke er truffet autoritative afgørelser. ${ }^{83}$ )

Fors $\phi g$ med en sadan handlingsorienteret og kvalitativ participation er gjort på lokalt plan, bl.a. i forbindelse med forskellige planlove. ${ }^{84)}$ Derimod har participationsfunktionen kun $i$ begrænset omfang sat sig igennem på centralt niveau, og $i$ den officielle statslige redegørelse for samfundskommunikation i Danmark har man eksplicit understreget, at information "som led $i$ en beslutningsproces ... i hovedsagen falder uden for udvalgets kommissorium." 85)

Udvalget erkender, at information af denne art "må påregnes at have en positiv effekt på de traditionelle demokratiske procedurer omkring det reprasentative demokrati". Når beslutningstagerne alligevel lader problemet ligge, kan det skyldes, at man finder reel participation på centralt niveau urealistisk, eller at participations-intentionerne kommer i strid med modgående interesser. Politologer har săledes påvist, at en for stor folkelig participation og direkte indflydelse $i$ politikken kan true den herskende orden, og at politisk apati inden for visse grænser kan bidrage til styreformens stabilitet. Hertil kommer, at statslig informationsvirksomhed $f \phi r$ og under beslutningsprocesserne let kan forekomme "partisk" og derfor svække opfattelsen af staten som neutral og hævet over sarinteressernes artikulation og aggre-

82) Willy Martinussen, Fjerndemokratiet. Social ulikhet, politiske ressourcer og politisk medverking i Norge, oslo 1973.

83) Kenneth Abrahamsson, Samhällskommunikation - Om kontakten mellan myndigheter och medborgare, Iund 1972, pp. $187 \mathrm{f}$.

$84)$ Gottschalk \& Tonboe, op.cit., jvf. lov af 13.6.1973 om landsog regionsplanlægning og lov af 10.6 .1975 om kommuneplanlægning.

85) Betankning 787-1977, p. 9. 
gation. ${ }^{86)}$

Hvilke overvejelser, der har været afgфrende, lader sig ikke endeligt afgфre. Givet er det dog, at man i samfundskommunikationen $i$ dag arbejder inden for en snæver repræsentativ demokratiopfattelse, og det, der kan betegnes som informationsvirksomhedens demokratiske participationsfunktion, er $i$ praksis alene oplysning om borgernes rettigheder og pligter, d.v.s. ${ }^{87}$ )

"Udvalget forstår sit kommissorium således, at det $i$ det væsentlige er begrænset til spørgsmål om information vedrørende vedtagne (fastsatte) retsregler, herunder navnilg love, bekendtgørelser og cirkulærer."

Der er altsa tale.om information som retssikkerhedsgaranti, som nok skal sikre borgernes mulighed for at varetage deres interesser og dermed deltage $i$ det politiske system, men forst efter en autoritativ afgørelse er truffet. Dette kan ses som en videref $\phi-$ relse af 1950'ernes bestrabelser, hvor staten etablerede en rakke repræsentative organer, der pă borgernes vegne skulle udøve kontrol med myndighederne. Det drejede sig bl.a. om ombudsmandsinstitutionen og forskellige ankenævn.

Fra slutningen af I960'erne taler man desuden om, at myndighederne har en informationspligt over for borgerne. Begrebet er lanceret af Danske Dagblades Fællesrepræsentation, ${ }^{88}$ men det er tvivlsomt, om en sådan pligt kan betegnes som en juridisk realitet, hvilket bl.a. Eastslås af dr.jur. Ole Krarup: ${ }^{89}$ )

"I grundlovens $\$ 22$ foreskrives det, at love skal kundgфres, men i praksis opfattes denne kundgфrelsespligt som opfyldt gennem en bestemt teknisk procedure, nemlig offentliggørelse $i$ Lovtidende. Herudover kan man ikke formulere nogen informationspligt for det offentlige ..." Krarup mener dog, at "det var rimeligt, om man efterlevede grundlovens krav om kundgørelse med tjenestelige midler", og pressejuristen Knua Aage Frøbert, Institut for Presseforskning, går et

86) Se de generelle overvejelser om folkelig deltagelse og repræsentativt demokrati i Betankning 798-1977, pp. $14 \mathrm{f}$. For en en almén indføring i den politologiske demokrati-debat se Palle Svensson, "Demokrati og politisk deltagelse" i Festskrift til Erik Rasmussen, Arhus 1977, pp. 273-304.

87) Betankning 787-1977, p. 9.

88) Redegørelse fra DDF af 15.6.1968.

89) Nordisk Administrativt Tidsskrift, 1970, p. 317. 
skridt videre, idet han finder belæg for en informationspligt i de hensyn, som motiverede offentlighedsprincippet $i$ loven om offentlighed $i$ forvaltningen fra 1969, og 90 )

"Alene forvaltningens pligt til at føre lovgivningen ud $i$ livet skaber således en nфdvendighed for informationsvirksomhed fra de administrative myndigheders side."

På dette grundlag bekræfter de statslige kommissioner eksistensen af en de facto informationspligt i staten. 91) I første omgang drager man den konsekvens, at informationsvirksomheden især bør sigte på de særligt berørte eller repræsentative institutioner, f.eks. interesseorganisationer og advokater. Men senere forskydes interessen $i$ retning af en oplysningspligt over for befolkningen som helhed.

I den seneste betænkning er informationspligten suppleret med en anden begrundelse for $\phi$ get oplysning som participationsgrundlag: et onske om at nå ud til de "informationssvage", d.v.s. mennesker, der har mindre information end gennemsnittet og som ofte også vil være svage $i$ andre sammenhænge p.g.a. deres placering i produktionsprocessen, uddannelse etc. 92)

Udvalgsflertallet mener, at "en vel tilrettelagt informationsvirksomhed kan bidrage til at løse et sadant ulighedsproblem", men anviser kun almene og generelle oplysningstiltag som midler $i$ et sådant projekt.

Dermed sidder udvalget forskerne - herunder sin egen ekspert Iic.merc. Preben Sepstrup, Media-Forsk, - overhørig. 93) Den (sparsomme) forskning på området synes således at vise, at man kun i meget begrænset omfang kan hjælpe de dårligt stillede gennem information alene. De er ikke kun "informationssvage" men "ressourcesvage", d.v.s. at sociale forhold kumulativt svækker deres situa-

90) Betænkning 714-1974, p. 15 .

91) Betænkning 536-1969, pp. 63 ff., Betænkning 641-1972, p. 11, Betænkning 787-1977, p. 14 .

92) Betænkning 787-1977, p. 44, jvf. Preben Sepstrup, "Om borgernes forbrug af information med særligt henblik pa statslig information", ibid., pp. 107-121. Se også om begrebet "informationslavaktive" i den såkaldte Rigsted-undersфgelse foretaget for Danske Dagblades Udgiverforening af Gallup Markedsanalyse 1976 og Schledermanns problematisering af begrebet $i$ Retfærd, nr. 5-1977.

93) Preben Sepstrup, op.cit., pp. $119 \mathrm{ff}$. 
tion $i$ samfundet. Derfor må selve deres sociale situation ændres, hvis lighed skal opnås, og vil man mildne problemet må der vælges en selektiv informationsstrategi, der anvender et sprog og nogle medier, som disse befolkningsgrupper benytter $i$ det daglige, d.v.s. radio-tv, ugeblade og distriktsblade.

Når man imidlertid ikke fra ansvarligt hold kan følge forskningens anvisninger m.h.t. participationsfunktionen hænger det bl.a. sammen med, at en sådan lighedsbestræbelse kommer i konflikt med den liberalistiske lighedsgrundsætning, jvf. afs̈nit 2.4 .

\subsection{Pressest $\varnothing t t e$}

Også de фkonomiske krisetendenser har sat sine spor i tilrettelæggelsen af statens informationsvirksomhed. Sammenkædningen af formidlingsproblematikken og spørgsmålet om indirekte pressest $\varnothing$ tte framgår bl.a. af, at debatten om samfundskommunikation er blusset op i perioder med $\phi$ konomiske problemer for dagspressen f.eks. i midten af 1960'erne og begyndelsen af 1970'erne, ligesom pressens synspunkter har været toneangivende $i$ de statslige kommissioner.

I de gældende retningslinier for statslig information understreges det, at dagspressen er den væsentligste kanal. Derimod skal ugeblade, distriktsblade og fagblade kun indgå $i$ begrænset omfang, og fra disse brancher har der da også været røster fremme om, at den udvidede statslige annoncering virker diskriminerende. ${ }^{94)}$

På dagsbladsomradet udelukker statens annonceregler til gengæld diskrimination: ${ }^{95)}$

"Skфnnes der at være behov for at iværksætte annoncering om retsforskrifter eller administrative dispositioner eller forebyggende kampagner, b $\phi r$ dette ske ud fxa forudsatningen om, at den enkelte borger ikke kan forventes at holde eller læse mere end en enkelt daglig avis. Det må derfor anses for rigtigst, at annoncering så vidt muligt omfatter samtlige dagblade, dog således at annoncering -

94) Se f.eks. henvendelser fra Distriktsbladenes Sammenslutning og Dansk Magasinpresses Udgiverforening optrykt i Betænkning 787-1977, pp. 124-130.

95) Økonomi- og budgetministeriets vejledning nr. 238 af 3 . november 1972, punkt I.5. 
såfremt forskriften eller dispositionen kun vedrører et klart afgrænset område af landet - begrænses til dagblade, eventuelle andre blade, i det pågældende område."

Reglen er en konsekvens af den liberalistiske lighedsgrundsætning. For det første opfattes borgerne som lige, hvorfor ingen gruppe, f.eks. "de ressourcesvage", har krav på særbehandling. For det andet er dagbladene ligeberettigede, hvorfor staten ikke må skabe konkurrenceforvridning gennem selektivt medievalg.

Pressest $\varnothing$ te-funktionen lader sig yderligere begrunde $i$ ideen om den borgerlige offentlighed: En forudsatning for demokratiet er åben debat bl.a. gennem pressen. "Bladdøden" og den deraf $f \varnothing l g e n d e$ monopolisering af pressen er derfor en trussel imod den frie meningsdannelse, hvorfor det må være en legitim statsopgave, f.eks. gennem pressest $\phi t t e$, at s $\phi g e$ opretholdt en $\mathbf{s}$ pluralistisk presse som muligt.

En måde at støtte pressen på er at фge den statslige og kommunale annoncering $i$ dagbladene. Imidlertid viser forskning på området, at en sådan generel og indirekte støtte ikke er særlig effektiv: ${ }^{96}$ )

Fælles for de generelle støtteforanstaltninger er, at de ikke har haft nogen reel betydning for pressens strukturudvikling. Snarere kan man tale om nogle "branchevenlige" foranstaltninger, som har kunnet formilde det фkonomiske klima, men næppe forhindre blade $i$ at mátte lukke."

Hertil kommer, at den indirekte støtte ikke skaber grundlag for oprettelsen af nye blade, ligesom hensynet til lighedsgrundsatningen $i$ praksis er problematisk, idet en række medier helt holdes ude, og de forskellige dagblade farr meget forskelligt udbytte af den statslige annoncering. 97 )

Også anskuet ud fra statens informationsvirksomheds $\phi v-$ rige füktioner er fremhævelsen af dagspressen og kravet om ligelig annoncering uheldig. Reglerne gør kampagnerne ekstraordinært omkostningskrævende, og i sparetider kan de virke prohibitive for en $\varnothing g e t$ kvantitativ informationsindsats og helt umuliggøre kva-

96) Ole John Poulsen, op.cit., p. 32.

97) Jvf. Statens Informationskontors notat af 12.11.1975 om den beløbsmassige fordeling af en $\phi g e \bar{t}$ informativ annoncering $i$ dagbladene og Danske Dagblades Udgiverforenings notat af í.i. 1976 om den procentvise for $\varnothing \mathrm{gelse}$ af hvert dagblads annonceindtægt ved en udvidelse af det offentliges annoncering med 10,20 eller $30 \mathrm{mill}$. $\mathrm{kr}$. 
litative forbedringer af informationen, f.eks. i form af mere selektive tiltag og medievalg.

Når pressest $\phi$ tte-funktionen imidlertid trods intentioner om det modsatte stadig indtager en fremtrædende plads i overvejelserne omkring statslig information, skyldes det bladudgiverne og en del politikere, der mener, at den private dagspresse lettere bevarer sin uafhængighed af statsmagten under indirekte end ved direkte og selektiv pressest $\phi$ tte.

Heller ikke dette er imidlertid givet. Som navnt under afsnit 2.2. skal statens Informationskontor nu s $\phi$ ge annoncerne placeret på en sådan måde, at de kan støttes af redaktionel tekst, og på baggrund af en lang række andre st $\phi$ tteordninger, f.eks. moms-fritagelse, reducerede posttakster, et statssubventioneret finansieringsinstitut o.s.v., er det nxppe sandsynligt, at en støttepolitik, der går ud over statens almindelige informationsvirksomhed, ville svække dagspressens formelle uafhængighed i større omfang. Til gengæld ville en række uhensigtsmæssige og blokerende elementer $i$ grundlaget for en samlet informationspolitik blive ryddet af vejen.

Hvor $\phi$ nsket om støtte til dagspressen er nogenlunde bevidst hos de politiske beslutningstagere, findes der ingen autoritative tilkendegivelser af, at staten bør støtte andre erhvervsgrupper gennem sin informationsvirksomhed. Også andre dele af reklamebranchen - herunder især de store reklamebureauer - har imidlertid store fordele af den nuværende aktivitet, der som regel iværksættes gennem private firmaer. Således har staten endnu ikke sikret sig en større del af rabatten på storreklamen, og kun Rådet for Stфtte Færdselssikkerhed har intentioner om selv at gennemf $\varnothing$ re sine kampagner, hvorimod det f.eks. i relation til statens Informationskontor stadig forudsettes, at den praktiske udf $\phi$ relse af informationsvirksomheden skal organiseres i privat regi. ${ }^{98)}$

\section{Råd og resultater}

Undersøgelsen viser, at spørgsmålet om $\phi$ get statslig information ikke er så uproblematisk, som det ofte fremstilles $i$ den danske debat. Information er hverken et gode eller et onde i sig

98) Rådet for Stфtte Færdselssikkerheds notat af 26.8.1976, jvf. Betænkning 787-1977, p. 92 og 55ff. 
selv, og problemerne løses derfor ikke ved helt at opgive den styrede information og dermed overlade opgaven til det privat initiativ: ${ }^{99)}$
"Den ligegyldighed, som man har vist problemet om tjene- stemændenes aktive forhold til offentligheden... har den virkning, at pressen, det er $i$ Kфbenhavn særlig den să- kaldte frokostpresse, jagter det offentlige og de offent- lige tjenestemænd som ofre, der om jeg så må sige, giver publikumsmæssig gevinst hver gang. Det er f.eks. skatte- myndighederne og sociale institutioner, som gang på gang hanges ud."

Men det er heller ingen heldig løsning blindt at anvende den centralstyrede information for derigennem at neddampe de bagvedliggende samfundsproblemer: ${ }^{100}$.
Effekten av... informationsverksamhet blir som så ofta annas att problemen informeras bort $i$ stället för att lösas med hjălp av reella förändringar av de konkreta förhällanden som skaper dem, ex. brist på arbettilfällen och social service. Den centrala information fungerar $i$ den situation främst som ett ideologiskt utanverk."

$\mathrm{På} \mathrm{den} \mathrm{ene} \mathrm{side} \mathrm{kan} \mathrm{den} \mathrm{udvidede} \mathrm{statslige} \mathrm{informationsvirksomhed}$ hjælpe med til at legitimere styreformen, styrke samfundsstyringen, $\varnothing g e$ administrationens effektivitet, støtte pressen og udgфre en nфdvendig (men næppe tilstrækkelig) forudsætning for $\phi g e t$ folkelig participation.

$\mathrm{På}$ den anden side indebærer statsstyret information risiko for propaganda, den kan virke ensrettende og handlingslammende og give store dele af befolkningen en følelse af pseudo-participation.

En del af disse problemer er strukturelt betingede og lader sig næppe afbøde gennem bevidst politisk adfærd. Imidlertid er den første forudsætning for en hensigtsmæssig informationsvirksomhed, at man erkender problemernes eksistens og tager kommunikationskritikken alvorligt. Desuden kan problemerne reduceres $i$ omfang, hvis der tilvejebringes yderligere to forudsætninger, som endnu ikke eksisterer $i$ Danmark: I) en bevidst afklaring af den overordnede kommunikationspolitik og dens målsætninger; 2) mere forskning omkring informationsvirksomhedens tilrettelæggelse og effekt.

99) Ole Krarup, Nordisk Administrativt Tidsskrift 1970, p. 318. 100) Jan Ekecrantz, op.cit., pp. $70 f$. 
Der findes ingen samlet dansk kommunikationspolitik. ${ }^{101}$ ) En række udvalg m.v. har uafhængigt af hinanden unders $\phi$ gt afgrænsede hjørner af problemstillingen, men bestræbelserne er aldrig blevet koordineret.

Det er en medvirkende årsag til, at de eksplicitte og implicitte målsætninger for informationsvirksomheden er uafklarede eller direkte strider mod hinanden. Onsket om forbedret statslig legitimation svækker således mulighederne for reel folkelig participation, og pressestøtte-aspektet hindrer de nødvendige selektive tiltag $i$ relation til retssikkerhedsproblematikken.

I stedet for som nu at satse på mange mål på ên gang, må forudsætningen for en effektiv informationsindsats derfor være, at man, $f \phi r$ informationsapparatet ekspanderer og prages af administrativ inerti, foretager en bevidst prioritering af de funktioner, den kommende virksomhed bør have.

Vil man alene satse pa legitimations-funktionen, er de hidtidige foranstaltninger stort set hensigtsmæssige, men må dog udvides kvantitativt.

Ex målet en opprioritering af styrings-funktionen, må informationsvirksomheden $i$ hфjere grad, end tilfaldet er i dag, målrettes til de sarlige institutioner og grupper, de pågældende emner tager sigte på.

Det bør desuden overvejes, $i$ hvor høj grad en centralisering af informationsformidlingen er hensigtsmessig. Vejen til dette delmål er sandsynligvis en kombination af statens Informationskontor som koordinerende overhead-organisation kombineret med informationsmedarbejdere $i$ de enkelte ministerier og styrelser samt et snævert samarbejde med oplysningstjenester $i$ kommuner og andre decentrale forvaltningsorganer.

Endelig b $\phi x$ man overveje, om det er hensigtsmassigt at satse på journalister $i$. informationstjenesten, eller om opgaven

101) Det er dog $i$ de seneste år gentagne gange blevet bebudet, at en medie-kommission efter svensk mønster skulle nedsattes med informationspolitikken som kommissorium. Et første skridt er gjort ved kulturministerens bibliotekskommission af 8.1.1976, der angiveligt er nedsat "som et led $i$ udformningen af en national informations- og bibliotekspolitik", jvf. kommissionens foreløbige rapport (december 1976), p. 2 . 
kan overlades til administrative uddannet personale. Ingen af disse faggrupper opfylder i dag de nødvendige kvalifikationskrav. Journalisterne er opdraget $i$ en pressetradition, der understreger nyhedskriterierne, mens administratorerne er rundet af en overvejende juridisk tradition. Det forekommer derfor mere hensigtsmassigt at satse på en specialuddannet administrativ-informativ ekspertise, der kan forene elementer fra begge faggrupper og indgå som stabsorganer $i$ centraladministrationen. 102)

Fremsættes et eksplicit фnske om folkelig participation, må man først og fremmest gøre sig klart, at det kan svække andre informationsfunktioner, og at den nuværende informationsvirksomhed da må andres kvalitativt.

Informationen må begynde tidligt $i$ beslutningsprocessen, d.v.s. før en autoritativ beslutning er truffet, og i stedet for alene at satse på envejs-formidling fra myndigheder til borgere, må der anlægges en kommunikationsstrategi. Der må sikres materielt grundlag for ytringsmuligheder og effektiv feed-back fra grupper uden for forvaltningen, og disse grupper må sikres flere ressourcer i kommunikationsprocessen.

En reel folkelig participation på individ-niveau er næppe realistisk i statslig regi, og utopien om "trykknap-demokratiet", hvor alle beslutninger sendes ud til ja/nej-folkeafstemninger i intim-sfæren, vil kun resultere $i$ gget manipulation og irrationalitet. Derimod må deltagelse af flere bevægelser og grupper ud over de store interesseorganisationer og professionelle kommunikatorer - ud fra en participations-målsætning - anses for at være både ønskelig og realisabel.

Hensynet til folkelig deltagelse og kontrol må desuden betyde, at der $i$ hфjere grad gives opfllgnings-og situationsinformation og ikke kun nyhedsinformation om love m.v. ${ }^{103)}$ Centralsty-

102) Planer for en sådan uddannelse bl.a. på Roskilde Universitetscenter, jvf. Betænkning afgivet af undervisningsministeriets udvalg af 2.7.1974, Roskilde 1975, pp. 54-71, er ikke blevet realiseret. Derimod har man gennem korte kurser på Den kommunale Højskole og Forvaltningsh $\varnothing j s k o l e n$ søgt at bibringe administratorer forståelse for informationsproblemerne, ligesom en gruppe statskundskabsstuderende på fors $\phi g s b a s i s$ har gennemgået et et-årigt kursus i praktisk journalistik på Danmarks Journalisth $\varnothing$ jskole $i$ Århus.

103) Jvf. også Betænkning 787-1977, pp. $34 \mathrm{f}$. 
rede informationskampagner kan kun støtte, men aldrig overflфdiggøre den integrerede og personlige kommunikation $i$ de enkelte forvaltningsorganer.

Diffuse mål-enheder som f.eks. "de informationssvage" må differentieres, idet de er baseret på en uhensigtsmæssig opfattelse af individet som kommunikationsenhed. I stedet kan man udbygge oplysningen af særligt berørte grupper, der må informeres (og hjælpes) ud fra deres konkrete placering i produktionsstrukturen, d.v.s. ud fra en kortlægning af udvalgte befolkningsgruppers materielle situation med det formal ikke blot at informere, men at løse de bagvedliggende samfundsproblemer.

Satsning pa de hidtil nævnte funktioner betyder, at der må gøres mere bevidste bestræbelser på at adskille informationsproblematikken fra pressestotte-funktionen. Den nuværende dobbeltholdning, hvor man $i$ ord hævder at se bort fra pressens specielle behov, men $i$ handling $i$ høj grad lader sig styre af dagbladenes sarinteresser, er ikke blot uhensigtsmassig, men har i perioder betydet, at alle andre delmå er blevet forflygtiget. En løsning på dette dilemma er at slå ind på en mere konsekvent, selektiv og direkte pressestøtte, så det bliver de nyetablerede og svagt funderede blade, der far hjælp. Derefter vil den statslige information gennem annoncer m.v. i fremtiden alene kunne ske ud fra фnsket om at opnå den maksimale oplysnings-effekt.

Det må ske $i$ sammenhæng med den sidstnævnte forudsætning for mere hensigtsmassig informationsvirksomhed: maling af effekt. I modsætning til den svenske praksis, hvor selve informationsarbejdet er snævert integreret $i$ en forskningsovervågning gennem Nämmnden för Samhällsinformation, sker analyser af kampagner og anden information $i$ Danmark tilfældigt og styret af afsenderen eller kommercielle interessegrupper.

ofte er der overhovedet ikke afsat midler til en opf $\phi l g-$ ning af virksomheden, hvorfor værdifulde erfaringer går tabt, og risikoen for at gentage fejl $\phi$ ges. I de tilfælde, hvor unders $\phi g e l-$ ser er foretaget, har der alene været tale om frekvensmålinger, hvorimod indholdsanalyser, diffusionsforskning, dybdeinterviews og kommunikationskritiske behovsanalyser slet ikke er afprøvet.

En forudsætning for en effektiv uanyttelse af informationsmillionerne er derfor, at der afsattes midler og mandskab til for- 
beredende og opfølgende forskning $i$ forbindelse med informationsindsatsen. Samtidig vil en sådan forskning kunne afdakke de mest oplagte farer for manipulation og propaganda.

I praksis kunne det ske ved oprettelsen af et forskningsorgan uafhængigt af de informerende organer og private interesser, eller ved at sådanne opgaver blev udlagt til et eller flere af de institutter ved universiteterne og de højere læreanstalter, der allerede har den forn $\varnothing$ dne ekspertise til at gennemf $\phi$ re kommunikationskritiske unders $\phi g e l s e r$. 